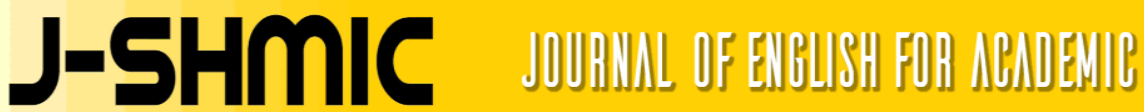

\section{Students' Perception of Using Whatsapp in Blended Learning on Reading Comprehension}

\author{
Liya Astarilla Dede Warman \\ STMIK-AMIK Riau \\ email: liya.astarilla@gmail.com
}

\begin{abstract}
This research aimed to investigate students' perception of using Whatsapp in blended learning on reading comprehension. This was a descriptive research. The participants of this study consisted of 40 students of the second semester at STMIK-AMIK Riau, Pekanbaru, Indonesia. The data collected through questionnaire and interview. The finding of this research showed that majority of the participants had positive perception towards the using Whatsapp in blended learning on reading comprehension. All of the means of students responses in the questionnaire in each items were at 3.5-4.5 which indicated students' responses were positive or at high level. The result from questionnaire also revealed that students agreed that using whatsapp in blended learning on reading comprehension was useful, helpful and effective in learning English anytime and anywhere. The findings from interview results also revealed that there were positive aspects and drawbacks of using Whatsapp in blended learning on reading comprehension. Nevertheless, the positive aspects of using Whatsapp in blended learning on reading comprehension gave more benefits to the students' learning activities and their performances. These benefits could be continued to students' learning outcome especially on their reading comprehension ability.
\end{abstract}

Keywords: Perception, Whatsapp, blended learning, reading comprehension.

\section{Persepsi Mahasiswa terhadapa Penggunaan Whatsapp dalam Blended Learning Pada Pemahaman Membaca}

\begin{abstract}
Abstrak
Penelitian ini bertujuan untuk menginvestigasi persepsi mahasiswa terhadap penggunaan Whatsapp dalam blended learning pada pemahaman membaca. Penelitian ini merupakan penelitian deskriptif. Partisipan dalam penelitian ini terdiri dari 40 orang mahasiswa semester dua di STMIK-AMIK Riau, Pekanbaru, Indonesia. Data dikumpulkan melalui kuosioner dan wawancara. Temuan pada penelitian ini menunjukkan bahwa mayoritas dari partisipan memiliki persepsi positif terhadap penggunaan Whatsapp dalam blended learning pada pemahaman membaca. Nilai rata-rata pada setiap item pada kuosioner adalah 3.5-4.5 yang mana ini mengindikasikan bahwa persepsi mahasiswa berada pada level yang tinggi atau positif. Hasil dari kuosioner juga menyatakan bahwa penggunaan Whatsapp dalam blended learning pada pemahaman membaca sangat bermanfaat, membantu, efektif dalam belajar bahasa Inggris kapan saja dan dimana saja. Temuan dari hasil interview juga menunjukkan bahwa ada beberapa
\end{abstract}


aspek positif dan kekurangan dari penggunaan Whatsapp didalam blended learning pada pemahaman membaca. Namun demikian, aspek-aspek positif pada penggunaan Whatsapp dalam blended learning memberikan manfaat terhadap aktifitas belajar dan kemampuan mahasiswa. Hal ini dapat berpengaruh pada hasil belajar mahasiswa selanjutnya khususnya pada kemampuan pemahaman membaca.

Kata kunci: Persepsi, Whatsapp, blended learning, pemahaman membaca.

\section{INTRODUCTION}

The continuing advancement of information and communication technology has contributed to new opportunities to enhance the accessibility and quality of education. The evolution of mobile technologies has affected learners' learning styles and teaching methods in educational environment where mobile devices have been applied. One of them is the using of mobile learning in teaching activity. The advantages of mobile learning include the convenience that comes with small and lightweight devices, the availability of space and time for learning, the adaptability of content according to individual needs, and the facilitation of sustained connections between learners and teachers. Moreover, mobile learning has potential aspect to increase flexibility by customizing the learning approach and to deliver a more personalized and learnercentered activity. This approach is supported by Geddes (2004) who state that mobile learning can extend opportunities for learning that can optimize the use of time and promote flexibility. Kukulska-Hulme and Traxler (2005) point out that mobile learning has an attributes that contributes to its term, namely; spontaneous, personal, informal, contextual, portable, ubiquitous, and pervasive. It means that these attributes refers to the mobile term itself so when it is utilized in education, it could provide the learning process everywhere and anytime. Furthermore, Mikic, et. al. (2007) believe that mobile learning has created a new learning environment that enables learners, through action learning aids, teaching materials, teachers and other learners, to learn at anytime and anywhere. It means that the fundamental feature of mobile learning is mobility and the convenient of learning anywhere and anytime.

Mobile learning has role in enhancing contextual and authentic learning practices on reading comprehension. It can enhance students knowledge by connecting the content of lesson into real life. It also helps the students to understand the topic discussed easier. According to Kukulska et.al (2009) mobile learning provided EFL students with substantial contextual opportunities that extended outside the classroom. It is not only stimulated collaboration and interaction between students, but also enhanced their contextawareness about their surrounding 
environment. In addition, students collaborated on interactive learning tasks by connected in-class learning activities and external context created from their class group via mobile learning community. In other words, students' successfully integrated several outer contextual topics that reflected their own environment into their classroom discussion through mobile device. The more the learning situation and activities resemble the students' reallife situation and tasks, the more the students will be motivated to learn, and the more relevant the learning will be. Furthermore, the learners' motivation is higher when the activities and the content are relevant to their lives. In addition, regarding to reading ability since students are familiar with the content, it helps them to focus more on details. As a result, it will help students in improving their reading comprehension. According to Dreyer and Nel (2003), teaching reading through technology facilitates student's involvement and increase motivation to learn. Moreover, Butler and Wiburg (2003) insist that technology can be a vehicle to practice reading skills based on each student's interests and needs by fulfilling a variety of purposes for reading. Moreover, Day and Bamford (1998) add that there is an increasing recognition that English reading provides great opportunities in improving language skills. Most EFL learning opportunities are usually classroom-based and/or teacher-centered rather than focused on students and their needs inside and outside of the classroom. However, there has been a growing interest in updating theoretical assumptions and new educational approaches and methods that can maintain effective learning, particularly, under collaborative, authentic, and meaningful conditions (Hu, 2002). In other words, technology or mobile device learning can support and enrich students knowledge, experience, and opportunities in learning reading.

In fact, many university students have insufficient exposure to English. Whereas, they have poor English ability, especially on reading comprehension. Majority of the students learn and use English only in classroom and they need more time to practice and learning outside classroom. The students only have 100 minutes in every meeting in classroom. Thus, lecturers need to give additional time outside classroom to the students to learn by giving more task and assignment to them. So, students are required to accomplish their assignment after class. In addition, according to the researcher observation, the students feel bored in doing conventional assignment or learning based on paper. Deal with the problem above, lecturers can support the teaching and learning activities through blended learning. Many experts have given their definition about blended learning really means. According to Singh and Rossett, blended learning is combining instructional modalities or combining instructional method (2002, 2007). Then, Young (2002) said it is combining online and faceto-face instruction. In addition, Sahin (2007) defined blended learning as kind of distance learning that is used 
to support face-to-face learning. In other words, blended learning incorporates all available technologies are used along with common classroom teaching. Furthermore, Trinder (2006:192) points out that blended learning can additionally help learners in developing 'autonomy, out-of-class learning, self-assessment, individualization'. Most importantly, it helps simulate work-related situations. Moreover, Elshenheimer (2006) states that blended learning should not only refer to mixing of training and delivery methods but also to the application of instruction, tools, practice, and evaluation to create unified learning and performance environment. Russell et.al (2003) argues that in blended learning, the students is actively involved in the learning process and has access to different online resources. In conclusion, through blended learning students learn more successful than just face to face or just online. It has the advantage of human contact and interaction. Finally, technology provides tools to encourage autonomous learning. From the definition above, it can be concluded that blended learning through technology language teaching become more flexible and make students' learning become more independent.

In addition, one of objective of learning for the undergraduate students is the students are able to apply their knowledge and technology in the real life (Indonesia Qualification Framework). To reach this goal, as a teacher or lecturer we can use technologies such as smartphone or android in blended learning. It can break the constraints of time, space and conditions in learning. Blended learning takes place where lecturer and students come together face to face on the one hand and use e-learning elements on the other hand. Although there are many useful mobile phone application can be used for the teacher in their classes, not all of them completely used by the students. The most ubiquitous application in smartphone among students is WhatsApp. Realizing the phenomenon above, the researcher encouraged to apply mobile learning in blended learning through WhatsApp for her students' reading comprehension. It is a smartphone application for instant messaging that provides several features. You not only can send message but also image, audio, video, and location. One of the great features of WhatsApp is its ability to facilitate communication via group. It uses the internet to send message, the cost of using it is significantly less than texting (short message service). This application is used ubiquitous for almost all mobile phone devices even for undergraduate students. The objective of this research was to investigate students' perception of using WhatsApp in blended learning on reading comprehension.

\section{METHOD}

This study was a descriptive research, which aimed to investigate students' perception of using WhatsApp in blended learning on reading comprehension. The study used a mixed-method design in terms of data collection, survey through 
quostionnaire and interview. Creswell noted that the use of these mixed methods approaches are particularly powerful when investigating one's own practice (2011). He also added the results of the study are more valid because they have been reinforced through multiple data collection methods. The participants of this study consisted of 40 students of the second semester at STMIK-AMIK Riau, Pekanbaru, Indonesia. This research was conducted in the second semester of 2016 academic year. The students were enrolled in English II course, Reading class. They met in class once a week. Each time covered 100 minutes. The length of the semester was 16 weeks. At the beginning of semester, the researcher created a whatsapp group where used for all of the participants. It was used for sharing information, assignments, materials or the link of the texts. Besides, it was a media for students to discuss their thoughts with peer or submit their assignment to the lecturer. It means that after learning reading comprehension in classroom, the students continued to learn reading comprehension through Whatsapp. The lecturer shared the information related to the assignment or a topic of discussion into whatsapp group once until three times a week.

Before conducting this research, the researcher constructed and evaluated the instrumentation. The draft of questionnaire originally contained of 15 items, but it was modified to suit with the research. The questionnaire was examined and validated by three experts. They

J-SHMIC, Vol 5, No 2, August 2018 checked the suitability of content and clarity instructions. They suggested to improve several items and also to delete three unnecessary items. The questionnaire used five point Likertscale. Each statement was answered from strongly disagree (1), disagree (2), slightly agree (3), agree (4), and strongly agree (5). The researcher adapted and modified the questionnaire based on Kelsen (2009) and Davis (1989) studies in order to make it more relevant to the students' learning objectives and the research objective. The questionnaire consisted of four parts. The first part of the questionnaire included demographic information of the participants including age, gender, levels of language proficiency. The second part consisted of three questions of the perceived ease of the use namely the easiness of using whatsapp in blended learning. The third part contained four questions of perceived usefulness namely the effectiveness of using whatsapp in blended learning, the last part consisted of five questions of the students' attitudes of using whatsapp on learning reading. These data were analyzed quantitatively for means and percentages by using Ms Excel. The ranges were used for this data as follows: $1.00-1.50=$ very low/very negative, $1.51-2.50=$ low $/$ negative, $2.51-3,50=$ moderate, $3.51-4.50=$ high/positive, $4.51-5.00=$ very high/very positive. In addition, for investigating the students' perception of WhatsApp in blended learning for reading comprehension more closely and getting a better insight into students' learning process through Whatsapp the students were interviewed in depth. The researcher 
adopted stratified sampling. The criterion of selection was based on important demographic information and performances. The researcher interviewed 15 students, 5 students who were active, 5 students who were in the middle, and 5 other students who were passive in classroom. They were asked to tell about their thoughts, positive and drawbacks of blended learning through WhatsApp. The data from interview was analyzed qualitatively. The researcher used triangulation design in analyzing quantitative and qualitative data which was different types but they were related each other in the same topic. These data were bring together into comprehensive interpretation (Creswell, 2011). The method design chart is shown in figure 1 , from data collection up to comprehensive interpretation.

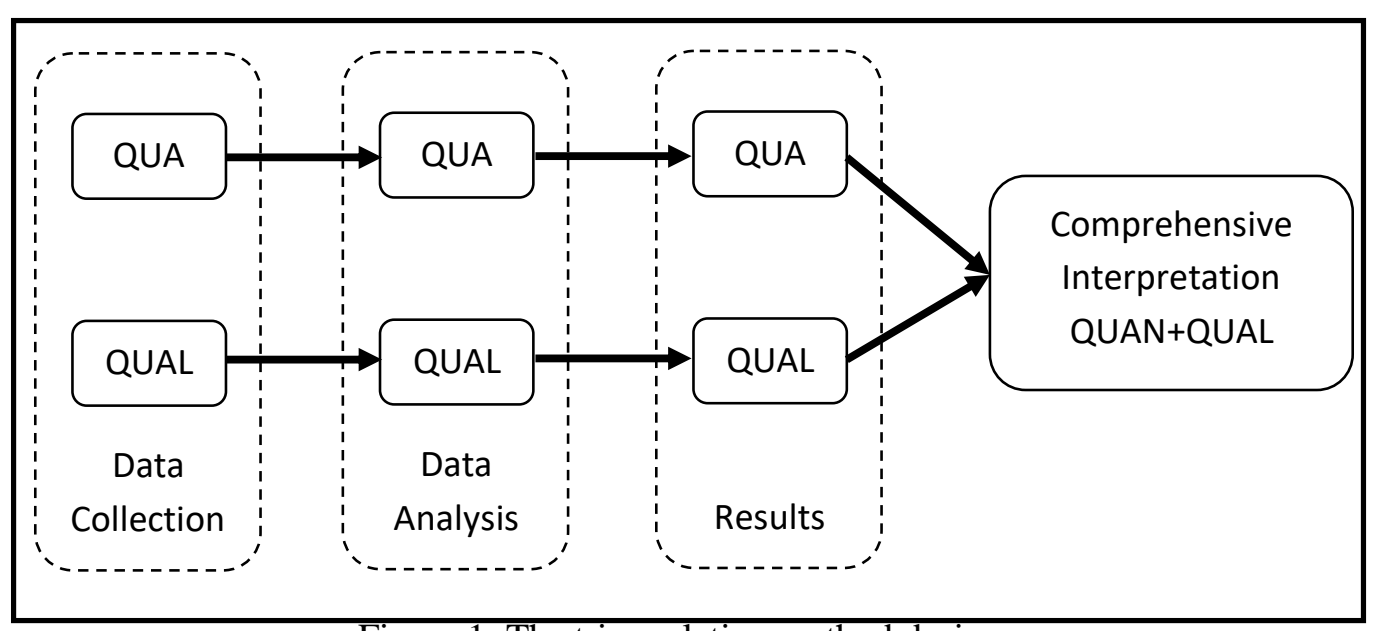

Figure 1. The triangulation method design

In the beginning of the research, the researcher ensured all of the participants have mobile phone, smartphone or android. Then, she asked all the participants to fill out a survey anonymously to keep an internal validity between the researcher and the participants. This was used as information about the participants activities of using smartphone. They were asked to choose the frequency of using mobile phone in a day. Table 1 showed that majority of students who used mobile phone for more than 3 hours in a day. From this table we conclude that almost of the students were active in using their mobile phone, smartphone or android. Furthermore, the researcher concluded that all participants could join this study.

Table 1 . Frequency of daily mobile phone use

\begin{tabular}{|c|c|c|}
\hline Average hour & Frequency & Percentage \\
\hline Between 1-2 hours & 3 & 7.5 \\
\hline Between 2-3 hours & 9 & 22.5 \\
\hline Between 3-4 hours & 17 & 42.5 \\
\hline Over 4 hours & 11 & 27.5 \\
\hline Total & $\mathbf{4 0}$ & $\mathbf{1 0 0}$ \\
\hline
\end{tabular}




\section{FINDING AND DISCUSSION}

The objective of this research was to investigate students' perception of using WhatsApp in blended learning on reading comprehension. After analyzing the data from students' questionnaire, the researcher found that the means

Table 2. The Easiness of using Whatsapp in blended larning

\begin{tabular}{|c|c|c|c|c|c|c|c|}
\hline \multirow[t]{2}{*}{ No } & \multirow[t]{2}{*}{ Questions } & $\begin{array}{c}\text { Strongly } \\
\text { Disagree (1) }\end{array}$ & $\begin{array}{l}\text { Disagree } \\
\text { (2) }\end{array}$ & $\begin{array}{c}\text { Slightly } \\
\text { Agree (3) }\end{array}$ & $\begin{array}{l}\text { Agree } \\
\text { (4) }\end{array}$ & $\begin{array}{l}\text { Strongly } \\
\text { Agree (5) }\end{array}$ & Mean \\
\hline & & $\%$ & $\%$ & $\%$ & $\%$ & $\%$ & - \\
\hline \multicolumn{8}{|c|}{ The Easiness of using Whatsapp in blended larning } \\
\hline 1 & $\begin{array}{l}\text { I think it is easy to interact and communicate with group members to } \\
\text { do reading discussion through WhatsApp. }\end{array}$ & 0,0 & 3,4 & 10,3 & 44,8 & 41,4 & 4,2 \\
\hline 2 & $\begin{array}{l}\text { I feel it is convenience to practice English Reading through WhatsApp } \\
\text { since I can access it anytime and anywhere. }\end{array}$ & 0,0 & 0,0 & 17,2 & 17,2 & 65,5 & 4,5 \\
\hline 3 & I see that whatsapp features are easy to use in learning and discussion. & 0,0 & 0,0 & 17,2 & 31,0 & 51,7 & 4,3 \\
\hline
\end{tabular}

Table 2 demonstrates that the participants agree that using whatsapp in blended learning for reading comprehension is easy to use whether for learning and discussion. The majority of the participants (65.5\% - 'strongly agree') approve that it is convenience learning reading through whatsapp since they of questionnaires from the easiness of using whatsapp in blended learning on reading comprehension in each items was at high level or positive. The result can be shown as follows: can learn and access it anytime and anywhere.

Table 3 presents that the result from questionnaire about the effectiveness using whatsapp in blended learning on reading comprehension was also at high level or positive. All the means from each items was at 4.0-4.4

Table 3. The Effectiveness of using whatsapp in blended learning

\begin{tabular}{|c|c|c|c|c|c|c|c|}
\hline \multirow[t]{2}{*}{ No } & \multirow[t]{2}{*}{ Questions } & \begin{tabular}{|c|} 
Strongly \\
Disagree (1)
\end{tabular} & $\begin{array}{c}\text { Disagree } \\
\text { (2) }\end{array}$ & $\begin{array}{c}\text { Slightly } \\
\text { Agree (3) }\end{array}$ & $\begin{array}{l}\text { Agree } \\
\text { (4) }\end{array}$ & $\begin{array}{l}\text { Strongly } \\
\text { Agree (5) }\end{array}$ & Mean \\
\hline & & $\%$ & $\%$ & $\%$ & $\%$ & $\%$ & - \\
\hline \multicolumn{8}{|c|}{ The Effectiveness of using whatsapp in blended learning } \\
\hline 1 & $\begin{array}{l}\text { I think using whatsapp in blended learning is effective way to improve } \\
\text { my reading comprehension anytime and anywhere. }\end{array}$ & 0,0 & 3,4 & 6,9 & 55,2 & 34,5 & 4,2 \\
\hline 2 & $\begin{array}{l}\text { I have opportunities to extend English reading outside the classroom } \\
\text { through WhatsApp and reading group discussion. }\end{array}$ & 0,0 & 0,0 & 13,8 & 31,0 & 55,2 & 4,4 \\
\hline 3 & $\begin{array}{l}\text { I think it is helpful to comprehend English reading through WhatsApp } \\
\text { after learning English reading comprehension in classroom. }\end{array}$ & 0,0 & 6,9 & 13,8 & 51,7 & 27,6 & 4,0 \\
\hline 4 & $\begin{array}{l}\text { I think it is good to learn English reading through WhatsApp since we } \\
\text { can read authentic materials. }\end{array}$ & 0,0 & 0,0 & 10,3 & 69,0 & 20,7 & 4,1 \\
\hline
\end{tabular}

Table above shows that $89.7 \%$ of the participants (the aggregated result of 'agree' and 'strongly agree') admitt that using whatsapp in blended learning is an effective way to improve their reading comprehension anytime and anywhere (mean score $=4.2 /$ high

level). Moreover, $86.2 \%$ of the participants agree that they have opportunities to extend English reading outside the classroom through whatsapp and reading group discussion (mean score $=4.4 / \mathrm{high}$ level). In addition, they also agree that whatsapp is helpful and it is 
good since they can read authentic materials for reading comprehension

Table below reveals the responses of the participants about their attitudes and perspectives on
(79.3 - 89.7\% of the participants/ 4.0-4.1).

using whatsapp in blended for reading improved or affected their attitudes.

Table 4. Students' Attitudes and perspective of using whatsapp in blended learning

\begin{tabular}{|c|c|c|c|c|c|c|c|}
\hline \multirow[t]{2}{*}{ No } & \multirow[t]{2}{*}{ Questions } & $\begin{array}{c}\text { Strongly } \\
\text { Disagree (1) }\end{array}$ & $\begin{array}{l}\text { Disagree } \\
\text { (2) }\end{array}$ & $\begin{array}{c}\text { Slightly } \\
\text { Agree (3) }\end{array}$ & $\begin{array}{l}\text { Agree } \\
\text { (4) }\end{array}$ & $\begin{array}{l}\text { Strongly } \\
\text { Agree (5) }\end{array}$ & Mean \\
\hline & & $\%$ & $\%$ & $\%$ & $\%$ & $\%$ & - \\
\hline \multicolumn{8}{|c|}{ Students' Attitudes of using whatsapp in blended learning } \\
\hline 1 & I have positive attitudes towards using whatsapp in blended learning. & 0,0 & 0,0 & 13,8 & 55,2 & 31,0 & 4,2 \\
\hline 2 & $\begin{array}{l}\text { I feel that learning reading comprehension through whatsapp is } \\
\text { interesting since we use technology. }\end{array}$ & 0,0 & 0,0 & 10,3 & 51,7 & 37,9 & 4,3 \\
\hline 3 & I feel enthusiastic learning reading comprehension via whatsapp. & 0,0 & 0,0 & 6,9 & 75,9 & 17,2 & 4,1 \\
\hline 4 & $\begin{array}{l}\text { I see it is challenging to do assignment or task through WhatsApp after } \\
\text { reading texts shared by the lecturer. }\end{array}$ & 0,0 & 3,4 & 34,5 & 62,1 & 0,0 & 3,6 \\
\hline 5 & $\begin{array}{l}\text { I feel comfortable to interact and communicate with friends for reading } \\
\text { discussion in mobile environment compared to in classes. }\end{array}$ & 0,0 & 6,9 & 6,9 & 75,9 & 10,3 & 3,9 \\
\hline
\end{tabular}

The findings from Table 4 shows that most $(86.2 \%)$ of the participants have positive attitudes towards using whatsapp in blended learning (mean score $=4.2 /$ high level). Besides, they also approve that learning reading for comprehension is interesting since the use of technology in learning. Furthermore, most of the participants feel enthusiastic learning reading via whatsapp. In addition, more than a half of the participants feel doing assignment or task through whatsapp is a challenging way. Finally, majority of the students feel more comfortable to interact and communicate with their friends related to assignment or task through whatsapp than directly discussion in classroom.

Furthermore, after collecting and analyzing data from interview, the researcher found various responses from the students about their thoughts of positive aspects of using WhatsApp in blended learning on reading comprehension, as following:

1) Students could learn English anywhere and anytime out of classroom.

2) Students think using whatsapp in blended learning is a cool learning style since they use smartphone and interrnet.

3) Students feel learning through whatsapp improved their motivation to read and comprehend the texts completely.

4) Students could read many kinds of texts even the hot issue topic, not only texts from textbooks.

5) Students could enrich their vocabularies during learning and discussion through whatsapp, therefore it helped 
them in comprehending English texts.

6) Students could also improve their speaking and writing skills.

7) Students thought it was an innovative way to improve their learning performances.

8) Students actively got involved in a discussion of reading texts given.

9) Students could share their opinion more free on the WhatsApp than in classroom.

10) Students could learn, communicate and discuss freely with lecturer and peer anytime and anywhere.

11) Students think it was faster way to submit assignments via whatsapp than email.

12) Using whatsapp in blended learning encouraged students to be more independent or improved their autonomous learning.

13) Students could do peer correction via whatsapp.

14) Students expect to continue using whatsapp for learning English in the future.

Several responses of the students above were in line with several researchers findings. Askari (2004) found that by using traditional textbook and online article in a course was more successful. It could be due to the up-to-date information and topics given by the teacher, which made them more relevant, interesting and thus more motivating for the learners to learn English reading. This finding also coincided with Bal and Arici study (2011) who stated that students are able to easily communicate with their tutors regardless of their location by means mobile learning. Next finding also congruent with Trinder (2006:192) who found that blended learning can additionally help learners in developing 'autonomy, out-of-class learning, self-assessment, individualization'. Furthermore, Arnó-Macià (2012) adds that by using mobile learning in blended learning, students could integrate both learning and enhancing their electronic literacy skills. These statements were correct as the findings of the researcher in this study that by using mobile learning in blended learning could give benefits to the students learning process and learning outcome.

On the other hand, several students also state their thoughts about the negative aspects of WhatsApp in blended learning on reading comprehension, as following:

1) They got difficulty in texting on small mobile phone screens.

2) The cost of the internet access on the mobile phone when they were far from the college, since at the college they can use free Wi-Fi access.

3) They must be online and use data in using whatsapp.

4) They got networks problems, especially for those who used unpopular provider phone card.

5) Several students have low speed in typing their thoughts on the WhatsApp. 
In conclusion, even though there were a few negative aspects of using WhatsApp in blended learning on reading comprehension, the positive aspects of it still gave more benefits to the students' learning activities and their performances especially in reading comprehension.

Finally, the result from questionnaire and interview illustrated that most of the students considered learning through WhatsApp in blended learning reading comprehension is useful and helpful. Majority of participants had positive attitudes towards using whatsapp in blended learning It is a effective way to improve their reading comprehension anytime and anywhere. Such findings were in line with Viola (2009) who states that blended learning has proved more successful than just face to face or just online. She adds that there is the advantage of human contact and interaction; and technology provides tools to encourage autonomous learning. Most importantly, it helps simulate work-related situations. She points out that 'the integration of digital media tools into a traditional face-to-face platform creates an optimal learning environment for language learning.' This statement is correct as the result of the previous experiment study that had been conducted by the researcher about the using of whatsapp in blended learning on students' reading comprehension achievement. She found that there was a significant effect in blended learning through WhatsApp undergraduate students' reading comprehension ability. We can conclude that the positive perception of using whatsapp in blended learning contributes to the achievement of students' reading comprehension.

\section{COCLUSION}

The findings of this research showed that majority of the participants had positive perception of using Whatsapp in blended learning on reading comprehension. All of the means of students responses in the questionnaire in each items was at 3.51-4.5 which indicated students' responses were positive or at high level. The result from questionnaire showed that students agreed that using whatsapp in blended learning on reading comprehension was useful, helpful and effective to support them in learning English anytime and anywhere. They also feel that using whatsapp in blended learning not only could improve their reading comprehension, but also improve their writing and speaking ability. Furthermore, the findings indicate that students have positive attitude towards the use mobile learning via whatsapp. However, based on the result from interview, the researcher found various positive aspects from the participants about the using WhatsApp in blended learning on reading comprehension namely students thought using whatsapp in blended learning was a cool learning style since they used smartphone and internet. Then, students could communicate and discuss freely with lecturer and peer anytime and anywhere. Besides, it improved students' motivation to read and comprehend the many kinds of texts completely. Furthermore, it could 
enrich students' vocabularies which influenced to their writing and speaking ability. In other hand, there were also drawbacks of using whatsapp in blended learning for reading comprehension namely internet access and networks problems. Then, several students also stated they got difficulties in texting or typing on small mobile phone screens. Nevertheless, although there were drawbacks of using WhatsApp in blended learning on reading comprehension, the positive aspects of it still gave more benefits to the students' learning activities and their performances. This benefit could be continued to their learning outcome especially on reading comprehension. in conclusion, there was positive perception of using whatsapp in blended learning on reading comprehension.

\section{REFERENCES}

Arnó-Macià, E. 2012. The Role of Technology in Teaching Languages for Specific Purposes Courses. The Modern Language Journal 96/Focus Issue: 89-104.

Askari-Arani, J. 2004. Internet-based Medical Articles in EMP. ESP World Journal 3/2. Available online at: http://espworld.7p.com/Articl es_8/Medical_A\%20.htm

Bal, Y., \& Arici, N. 2011. Mobile Learning material preparation process. Journal of Information Technology, 4(1), 7-12.
Butler-Pascoe, M.E., \& Wiburg, K.M. 2003. Using technology to teach reading and writing. In M.E. Butler-Pascoe \& K.M. Wiburg (Eds.), Technology and Teaching English Language Learners (pp. 114-137). Boston, MA: Allyn and Bacon.

Creswell, J.W and Plano Clark, V. L. 2011. Designing and conducting mixed method research (2nd Ed). Thousand oaks, CA: Sage Publication Inc.

Day, R. R and Bamford, J. 1998. Extensive Reading in the second language classroom. Cambridge: Cambridge University Press.

Dreyer, C and Nel, C. 2003. Teaching reading strategies and reading comprehension within a technology-enhanced learning environment. System, 31, 349-365.

Elshenheimer, J. 2006. Got Tolls? The blended learning analysis and design expediter. Centre for integrative Learning Performance Improvement, 45 (8), 26.

Hu, G. 2002. Recent important developments in secondary English-language teaching in the People's Republic of China. Language, Culture, and Curriculum 15, 30-49.

Kelsen, B.A. 2009. Teaching EFL to the iGeneration: A Survey of Using YouTube as Supplementary Material with 
College EFL Students in Taiwan. ResearchGate.

Kukulska-Hulme, A. and Traxler, J. 2005. Mobile learning: A handbook for educators and trainers. Cromwell Press.

Kukulska-Hulme, A. 2009. Will mobile learning change language learning? ReCALL 21, 157-165.

Mikic, F., Anido, L., Valero, E., \& Picos, J. 2007. Accessibility and mobile learning standardization. Paper presented at The Second International Workshop on MCL 2007.

Rossett, A. (ed.). 2002. The ASTD elearning handbook. New York: McGraw-Hill.

Russell, T,. Osguthorpe, C.R. Graham. 2003. Blended Learning Environment: Definition and Direction. Review of Distance Education, 4 (3), 227.

Geddes, S.J. 2004. Mobile Learning in the 21st Century: benefits for learners, "Knowledge Tree E- journal, vol.30, no 3, pp. $214-228$

Sahin, I. 2007. Predicting student satisfaction in distance education and learning environments. Turkish Online Journal of Distance Education-TOJDE, 8 (2), 113-119.

Singh, D. K. 2007. Effectiveness of online instruction: Online submission. (Online). Retrieved from: Www. Eric.ed.gov/ERICWebPortal/r ecordDetail $?$ accno=ED49898 7 (Januari 14, 2015)

Trinder, R .2006. 'Integration of Elearning into a Tertiary Educational Context', in Arnó, E, Soler, A and Rueda, C (eds) Information Technology in Languages for Specific Purposes: Issues and Prospects. New York: Springer, 191-210.

Warman, Liya Astarilla Dede. 2017. The Effect of Whatsapp in Blended Learning on English as Foreign Language (EFL) Undergraduate Students' Reading Comprehension. Proceeding of the Fifth International Seminar on English Language and Teaching (ISELT 2017). Atlantis Press.

Young, J. 2002. "Hybrid” teaching seeks to end the divide between traditional and online instruction. Chroncle of higher Education, 48 (28), 33. 